\title{
Ove Scavenius (1884-1973) - elev af Carl Nielsen
}

\author{
af seniorkonsulent, forskningsprofessor emeritus Niels Krabbe
}

I år 2000 blev den prangende hovedbygning på Klintholm nedrevet på grund af svamp. Bygningen, der var opført i Renæssancestil i 1875, havde længe været angrebet og kunne de sidste årtier ikke reddes, endsige anvendes til menneskebolig, og i løbet af 1980'erne blev inventaret fjernet. Blandt de mange vidnesbyrd om forrige tiders liv på godset var en række papkasser fulde af trykte og håndskrevne noder, som stammede fra komponisten Ove Scavenius, der som den næstyngste af ti børn af godsejer, Kammerherre Carl Sophus Scavenius og hustru Thyra Castonier, havde boet det meste af sin tid på Klintholm. Ove Scavenius var således bror til den senere statsminister Erik Scavenius.

I 1996 fik Det Kgl. Bibliotek et praj om disse kasser, som i mellemtiden var blevet flyttet til et sommerhus på Møn og taget i varetægt af et barnebarn af Ove Scavenius' broder, senere forskningsbibliotekar ved biblioteket, Alette Scavenius. Et selvsyn på stedet viste en meget omfattende samling - fortrinsvis af manuskripter i Ove Scavenius' hånd (men også mange trykte noder af Carl Nielsen med dedikation), bestående af en lang række færdige kompositioner og et væld af skitser, der både var læselige og ulæselige (faktisk bestod af lutter kruseduller); samlingen var stærkt beskadiget af fugt som følge af Klintholms bygningsmæssige stand gennem de foregående 30-40 år.
Hvad der i første omgang påkaldte sig en særlig interesse var, at adskillige af kompositionerne øjensynligt var gennemset og kommenteret af Carl Nielsen. Af denne grund, og fordi Ove Scavenius i forvejen var kendt som en - om end perifer person i Carl Nielsens biografi, takkede biblioteket naturligvis ja til i at modtage hele samlingen som gave fra familien med Alette Scavenius som talskvinde. I 1996 blev de fugtskadede kasser overført til biblioteket, og senere blev den bevaringsværdige del af materialet ordnet i kapsler uden en egentlig katalogisering på værkniveau. Her har materialet ligget siden, og med udgangspunkt i denne samling skal her gives en kortfattet introduktion til denne besynderlige komponist fra Carl Nielsens omgangskreds - både lidt om hans liv og lidt om hans værk.

I forlængelse af overdragelsen af papkasserne til KB foranledigede Alette Scavenius, at et par af Scaveniusfamiliens medlemmer fra generationen mellem Ove Scavenius og hende selv - det vil fortrinsvis sige Ove Scavenius' niecer og nevøer - nedskrev nogle af de erindringer, de havde om deres onkel, hvilket gav et forholdsvis entydigt billede af Ove Scavenius' karakter, og som også, indirekte, forklarede det forhold, Carl Nielsen havde til ham. Hertil kommer, at der i Rigsarkivet findes en større samling breve fra medlemmer af Carl Nielsen-familien til Ove Scavenius, som 


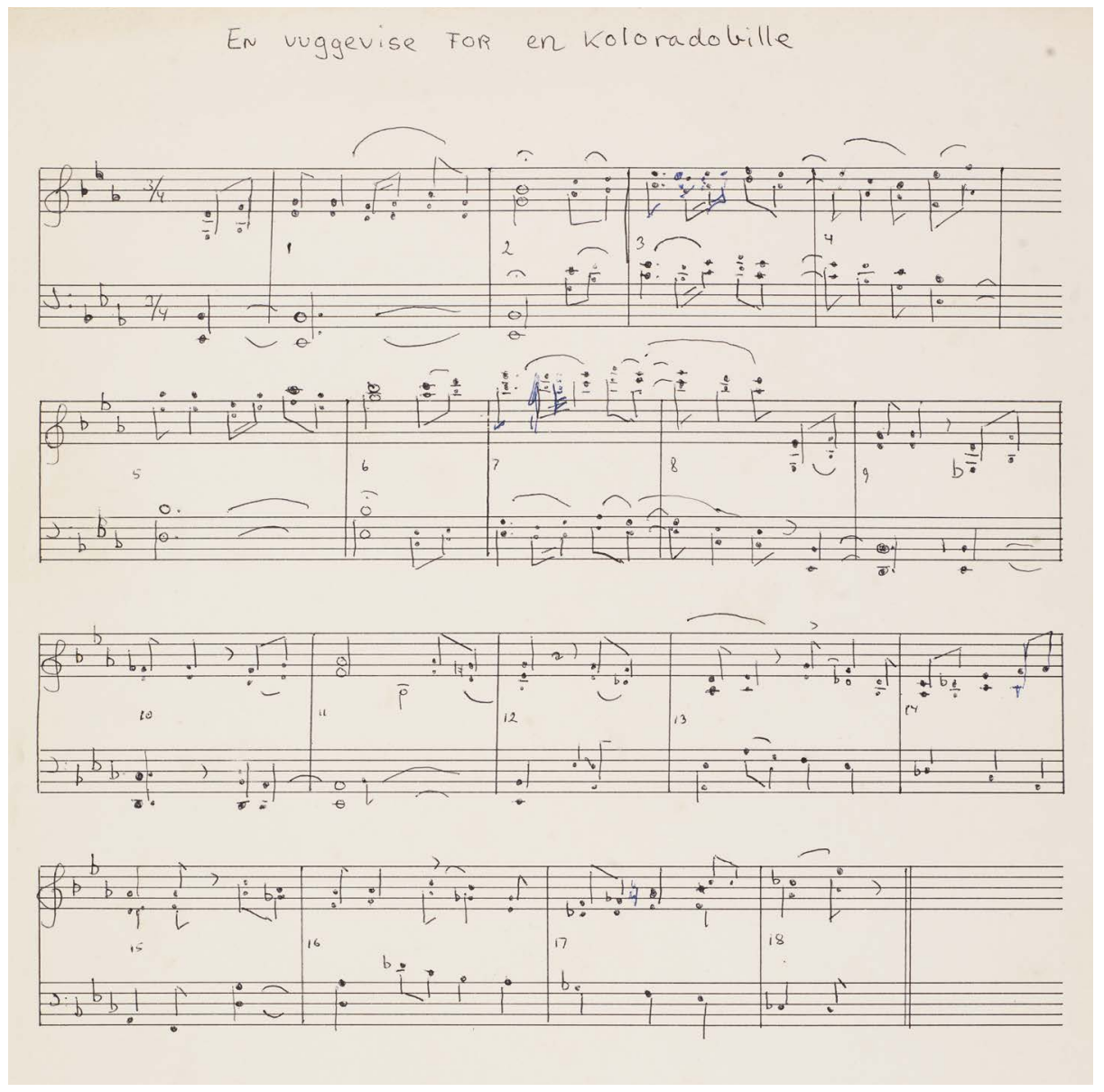

Scavenius' komposition til stotte for koloradobillen. Som det fremgär, er der tale om et meget sent verk, hvor nodeskriften er ganske vanskelig at lese.

tilsyneladende ikke tidligere har været kendt. ${ }^{1}$ Her er tale om breve fra både Carl Nielsen selv og hans hustru, men også - som det vil fremgå nedenfor - af de to døtre. Denne samling på mere end 100 breve fra perioden 1907 til hans død i 1973 viser, hvordan alle fire medlemmer af familien, hver på sin måde, har bekymret sig om Ove Scavenius og betragtet ham som en ven af familien.
Ove Scavenius' liv og personlighed

Ove Scavenius var som nævnt næstyngste barn af 10 søskende på Klintholm på Møn. Som barn blev han sat i en katolsk drengekostskole i Ordrup, men udviklede sig til et sygdomssvækket, tilbageholdende og lidt svageligt barn. Enslydende beretninger fortæller, at han var meget knyttet til sin mor, som lige til sin død i 1930 tog sig specielt af ham (faderen var død alle- 
rede i 1901). Hans musikalske evner viste sig tidligt, og han tilbragte store dele af sin barndom ved klaveret. Der synes ikke at være hel klarhed over, hvilken formaliseret musikalsk uddannelse han fik. En tid studerede han i Berlin, og omkring 1910 kom han på Musikkonservatoriet i København (formentlig med klaver og violin som hovedfag), men da han ikke optræder som dimittend i konservatoriets lister $\mathrm{i}$ årene $\mathrm{o.}$ 1910, må man antage, at han aldrig fuldførte uddannelsen. ${ }^{2}$ Han modtog formentlig nogen klaverundervisning hos Dagmar Borup, der selv senere blev lærer på konservatoriet (og med hvem han bevarede kontakten helt til hendes død i 1959), og formentlig både før og efter konservatorietiden var han privatelev og protegé af Carl Nielsen. Selvom han hele sit liv havde fast ophold på Møn, deltog dog han i et vist mål i det københavnske musikliv, hvor han havde sin gang $\mathrm{i}$ forskellige kunstnerkredse sammen med malere, digtere og andre komponister.

På Klintholm, hvor det angiveligt var Oves mor, der var den styrende kraft, indrettedes et par værelser i hovedbygningen, som tjente som Oves bolig og musikarbejdsværelse helt frem til o. 1940, hvor han købte en gård nær Klintholm, hvor han boede til sin død i 1973 - ugift men sammen med et ægtepar, til hvem driften af gården var forpagtet. På et tidspunkt, formentlig kort efter århundredskiftet, lod moderen bygge og indrette et lille træhus midt i skoven med loftsdekorationer udarbejdet af Ove bror, maleren Roger Scavenius, og forsynet med et klaver, hvor Ove kunne trække sig tilbage og koncentrere sig om sine tanker og sin musik. Huset er bevaret til i dag.

Når man tager Ove Scavenius' musikalske løbebane og uddannelse i betragt- ning og sammenholder det med den meget betydelige samling af renskrifter af især sange, der fandtes i papkasserne fra Klintholm, får man indtryk af en komponist, hvis ønsker og ambitioner ikke helt stod mål med den virkelighed, der blev hans og de resultater, han opnåede som kunstner. Meget tyder på, at dette bunder i hans personlighed. Familiens beretninger tegner billedet af en uhyre venlig og hyggelig person, som kun ville sine medmennesker det bedste, men som både var meget genert, og som samtidig havde yderst svært ved at bestemme sig og at holde fast ved sine beslutninger. I et af de nævnte breve fra 1996 hedder det:

"Ove var et stille, beskedent og ligevægtigt menneske - men faste meninger og hurtige beslutninger var ikke hans. [...] Han var vægelsindet og ubeslutsom, men lod sig let overtale, men bevarede sin tvivl."

En anden skriver, at han "... levede i sin egen drømmeverden, nogle gange glemte han at spise, maden kunne stå på bordet $\mathrm{i}$ timer."

Ovenstående karakteristik falder helt i tråd med Carl Nielsens beskrivelse af sin elev til en ukendt tredjemand:

"Jeg sender Dem en ung Mand, Ove Scavenius, der er noget af det fineste, beskedneste og mest tiltalende i denne Verden. Han siger ikke et Ord, maaske, men der bor en Sjæl i ham. Han er min Elev, men studerer nu i Cöln. Han er rimeligvis for tilbageholdende og angst for bede Dem om et Raad [om hvorvidt han skal flytte fra Cöln til Berlin].”3

To karakteristiske træk meddeles i flere af brevene fra familien: det ene er, at han 
gennem hele sit blev støttet af moderen, ikke mindst økonomisk (det var hende, som fik bygget huset i skoven til ham, og det var angiveligt hende, der skaffede midler til, at han som ældre kunne købe sin egen gård, ligesom det var hende, der forsørgede ham i det daglige og ledsagede ham på helbredende rejser til Italien). Den anden historie, som omtales af flere af informanterne og også nævnes $i$ hans nekrolog i Næstved Tidende, er hans bekymring over coloradobillernes skæbne, efter at man i 1972 havde sat en aktion i gang for at udrydde dem på Møn, hvor de åbenbart gjorde stor skade! I den anledning komponerede Ove Scavenius Vuggevise for en Koloradobille, som er overleveret blandt noderne i samlingen på Det Kgl. Bibliotek. ${ }^{4}$ Denne mærkelige, næsten ulæselige komposition bærer præg af, at Scavenius på dette tidspunkt havde svært ved at samle sig om kompositionsarbejdet. Ikke desto mindre beskriver nekrologen dette værk, "som han ofte spillede det sidste år" således: "en henrivende lille ting, som bevægede hans omgivelser meget. En af hans feriedrenge, der som den eneste har slået sig ned på Møn, optog den på bånd og er nu gemt væk til eftertiden."

Ovenstående karakteristik af Ove Scavenius bygger som sagt på erindringer fra hans slægtninge og vedrører således af gode grunde $i$ alt væsentligt de sidste 20-30 år af hans liv. De er naturligvis af meget privat karakter og har for en større kreds kun interesse, fordi han som yngre indgik i kredsen omkring Carl Nielsen, og fordi han har efterladt den meget store nodesamling i Det Kgl. Bibliotek. Det skal dog understreges, at de mange breve fra Carl Nielsen-familien til Ove Scavenius både giver et mere nuanceret billede af hans tilsyneladende ensomme og afsondrede liv og også antyder, at hans musik trods alt har været hørt og spillet lidt oftere, end man hidtil har troet.

\section{Ove Scavenius og Carl Nielsen}

Carl Nielsen synes at have næret en særlig hengivenhed - eller måske snarere beskyttertrang - over for den godt 20 år yngre Ove Scavenius. På et tidspunkt, måske allerede fra 1907 før sit ret korte konservatorieophold, blev Scavenius privatelev af Carl Nielsen i komposition, hvilket ikke mindst har sat sig spor i de mange kommentarer og rettelser i Carl Nielsens hånd, som kan ses i Scavenius' efterladte nodemanuskripter (se nedenfor) samt i en række breve til Ove. Undervisningen foregik dels ved personlige møder, dels pr. korrespondance, og gang på gang opfordrer Carl Nielsen sin elev til at fortsætte sine studier, så han kan udvikle sit talent og ikke mindst til at sende ham flere værker til kommentering! De følgende år - faktisk lige til sin død - forsøgte Carl Nielsen at hjælpe og opmuntre Scavenius både i sociale og musikalske sammenhænge. Nedenstående uddrag fra Carl Nielsens hidtil ukendte breve i Rigsarkivet fortæller mere end mange ord om karakteren af undervisningen:

“... Jeg ser helst at De skriver hver Uge mindst en Sang og vælger saadanne Digte hvor den strofiske Behandling er den naturligste samt de sædvanlige kontrapunktiske Opgaver. Jeg haaber at faa en stor Rulle en af Dagene, husk: Livet er kort og Kunsten langstrakt. Hilsen fra deres hengivne Carl Nielsen."

"Andanten [nodematerialet i KB afslører ikke, hvilket værk, der kan være tale om] 
overrasker mig og rent skolemestermæssigt set er der næsten intet at rette, derfor maa De blot fortsætte paa egen Haand til, vi ses. Nu beholder jeg Stykket til De kommer, men jeg vil gerne snart have en Sats til og nu kan de godt skrive i en friere Form naar blot De sørger for at Indholdet ikke derfor bliver for springende, med andre Ord lader Fantasien spille noget livligere men dog under Kontrol. Prøv enten en Menuet, Scherzo eller en lille halvlystig Allegretto."

En biografisk detalje i forlængelse af Ove Scavenius' regelmæssige sociale og faglige samvær med Carl Nielsen var, at hans datter, Irmelin, i årene mellem 1912 og 1918 var dybt forelsket i Ove Scavenius en følelse, som der dog ikke er vidnesbyrd om, var gengældt. Det er tilsyneladende følelser, som hovedsageligt har været drøftet mellem de to søstre, Anne Marie og Irmelin, og som forældrene ikke har været vidende om. I hvert fald er det påfaldende, at Irmelins forhold til Scavenius udelukkende omtales i brevene mellem de to søstre og aldrig nævnes i breve til forældrene. ${ }^{7}$ Meget tyder på, at der primært er tale om følelser, som Irmelin kun nødtvungent har villet udtrykke direkte overfor den tilbedte, men som hun med jævne mellemrum i indforståede vendinger kredser om i sin korrespondance med lillesøsteren. Første gang, emnet berøres, er i et brev fra Irmelin til Anne Marie, hvor den tryggende stemning $i$ hjemmet beskrives som følge af den ægteskabelige krise mellem forældrene ("Hvor er det dog trist at vores Hjem i den Grad er Melankoliens Bolig," hedder det bl.a. i brevet). Senere i brevet reflekterer Irmelin over, hvorfor hun ikke hører fra Ove Scavenius, som svar på de breve, hun har skrevet til ham. Særlig smerteligt bliver det, hver gang hun tænker på Møn og på Klintholm (hvor den tilbedte har rod). ${ }^{8}$ Et par år senere hører vi igen, hvordan Ove fylder hendes tanker - i hvert fald, når hun har tid. Midt i beskrivelsen til Søs af sit hektiske arbejde omkring Friluftsteateret i Dyrehaven skriver Irmelin:

"I dag har jeg ikke haft et roligt Øjeblik, jeg faar hverken Tid til at sanse eller samle mig, og OS ser jeg slet ikke og faar næsten ikke engang Tid til rigtigt at tænke paa ham - er det ikke frygteligt - kun naar jeg kommer i Seng."

Og værre bliver det to måneder senere, hvor Irmelin på en cykeltur til Fakse Ladeplads kan se over til Møn og beskriver situationen for Anne Marie: "Og saa blæste det og i selve Solskinnet kunde man endnu mærke Nattekuldens friske Pust - og saa havde det sunget inden i mig lige fra Morgenstunden Ove Ove." 10 Endelig i sommeren 1918 indser Irmelin, at forholdet til Ove Scavenius er frugtesløst, og i et langt brev til Anne Marie - på tysk, mærkelig nok - gør hun det klart, at affæren nu er forbi:

"Ich weiss dass du es gut meinst, du liebe Søs, aber es ist vorbei, ganz vorbei - ich habe dir es schon längst geschrieben, dass es für mich sehr viel war, dass ich es nie entbehren wollte obwohl es vielleicht vielmehr eine Fantasie für mich war. [...] Es ist richtig das ich muss weiter, aber nur mit das was ich geworden bin durch das vieles was ich durchlebt hat von schönes und schmerzhaftes." ${ }^{11}$

Godt et halvt år efter efter blev Irmelin forlovet med lægen Eggert Møller, som senere blev hendes mand. 
Ovenstående redegørelse for forholdet mellem Irmelin og Ove Scavenius bygger på de få breve, som hidtil har været kendt. Imidlertid giver den store brevsamling $\mathrm{i}$ Ove Scavenius' Samling i Rigsarkivet et mere indgående kendskab til sagen. Her er bevaret en række kærestebreve fra Irmelin til Ove fra årene 1912-1915, alle sammen domineret af hendes frustrationer over ikke at høre fra Ove: "Du slemme, slemme kære - jeg skriver ikke noget rigtigt Brev til dig, før du skriver. Jeg sidder kun ganske stille og hvisker tre smaa, korte Ord til dig. Mon du kan mærke hvad det er" ${ }^{12} \mathrm{Og}$ et par måneder senere hedder det kort og godt: "Paa Tirsdag, ja paa Tirsdag kære, saa ses vi igen. Paa Tirsdag. Irmelin." ${ }^{13}$

Det helt store drama synes at have været opstået, da moderen ved en fejltagelse er kommet til at åbne et brev fra Irmelin til søsteren, hvori hun fortæller om sig selv og Ove: "Efter at jeg hørte det har jeg raset og grædt - hvad synes du dog? Er det ikke grusomt. Far og Mor har ikke talt om det med mig direkte, men jeg ved jo at de har læst det. Det er ikke saa skrækkelig meget de har faaet at vide, men alligevel alt - alt for meget." 14

Endelig i juni 1919 meddeler Irmelin i et brev til Ove, ${ }^{15}$ at hun er blevet forlovet, men at hun håber, at de to fortsat kan være venner; at dette ønske gik i opfyldelse, fremgår af at de jævnligt mødtes og løbende stod i brevforbindelse med hinanden helt frem til 1973.

Carl Nielsen bekymrede sig virkelig om Ove Scavenius' musikalske karriere og søgte på mange måder at fremme hans gennemslag som komponist. Som et blandt mange eksempler på dette kan nævnes, at Scavenius i 1917 havde skrevet en firestemmig mandskor-sats til Jeppe Aakjærs salme "Tag min Sjæl, naaderige Gud.” Efter at have gennemset satsen skrev Carl Nielsen følgende til Aakjær, som mere end mange ord dels siger noget om Scavenius' karakter, dels om Carl Nielsens hjælpsomhed også i det rent kompositoriske:

"Komponisten Ove Scavenius (adresse Klintholm pr. Stege) har komponeret en overordentlig smuk og dybtfølt Melodi til Deres 'Tag min Sjæl naaderige Gud,' som er udsat for Mandskor. Imidlertid har han oprindeligt skrevet Melodien til 2det Vers, og saa bliver det galt med 1ste, idet 5te Linje har det stærke 'Satans Vingestræk.' Nu spørger jeg Dem paa hans Vegne - han er saa uhyre beskeden og genert, at han ikke selv tør henvende sig til Dem - om det kunde tænkes ved en eventuel Opførelse at forandre lidt paa første Vers saa vi fik et andet Ord end Satans eller maaske en mildere Form af denne Strofe. Det er kun af Hensyn til hans udmærkede Musik jeg beder Dem om at tænke over Sagen; vi synes naturligvis begge at det gamle barske 'Satans Vingestræk' er storartet men De forstaar at naar Melodien er strofisk gaar det knap saa godt. Kan der staa 'Skæbnens' eller 'Nattens' f.Ekspl.? Vær rar at tænke over det og send maaske Hr. S. et Brevkort, hans Musik fortjener i højeste Grad at komme frem. [...]."16

Da sangen kort efter forelå udgivet i en slags lystryk, var det dog stadig med den oprindelige "Satans Vingestræk" i første vers; ${ }^{17}$ Aakjær fulgte dog ikke opfordringen om ændringen, hvilket Carl Nielsen må fortælle Scavenius i et af sine breve. ${ }^{18}$ 
Bagsiden af den trykte udgave af Tre Sange - maske en illustration af Aakjers "Nu er det lange siden."

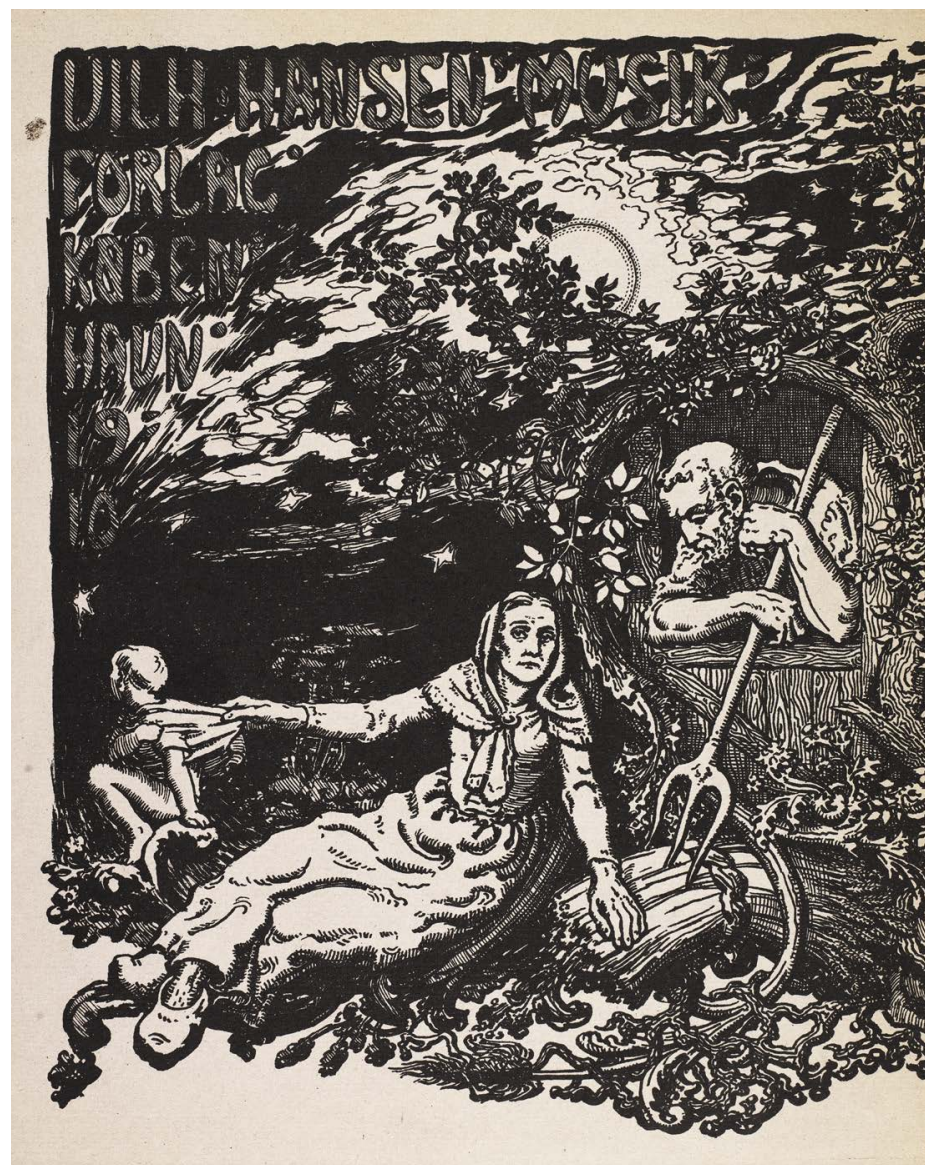

Studierne hos Carl Nielsen

Carl Nielsen omtalte et sted Ove Scavenius som "min kære Elev," og han gjorde, som antydet ovenfor, meget for at fremme hans musik, gennem henvendelser til forlag og sangbogsudgivere. Men først og fremmest underviste han ham i satslære og komposition, ligesom han gennemså en række af hans sange og forsynede dem med rettelser og kommentarer. Både af brevene og af det overleverede nodemateriale fremgår, at undervisningen primært er foregået på den måde, at Scavenius har sendt sine satser til Carl Nielsen, som derefter har kommenteret dem med korte bemærkninger, undertiden ligefrem med karakterer ("Mg," "Ug," "God," "For springende kontrapunkt," "NB Sludder Ove Scavenius"). Navnlig i årene mellem 1903 og 1911 findes talrige tilføjelser og rettelser i Carl Nielsens hånd i manuskripterne. Det drejer sig dels om en lang række kontrapunktopgaver efter den såkaldte "artslære" i Palestrinastil, som var den gængse metode til indføring $i$ elementær satslære for vordende komponister - en 
metode, der gik helt tilbage til 1700-tallet, og som i øvrigt senere blev forfinet af an anden af Carl Nielsens elever, Knud Jeppesen. ${ }^{19}$ Efter en af opgaverne har Carl Nielsen tilføjet følgende mere generelle bemærkning:

"Kjære S.! Der kan ingen kriminel Tiltale rejses mod Dem; men Fugen er for ensartet og man mærker De er angst for at gjøre Fejl og glemmer derfor at være opfindsom i det kontrapunktiske. For resten er det ret oplivende saa der bestandig er Fremgang enten i den ene eller den anden Henseende."

Og i et postkort skrevet under et besøg hos Nina Grieg på Troldhaugen i Norge skriver Carl Nielsen til Scavenius:

"Kære Scavenius! Send mig endelig hvad De har lavet og fremdeles laver [...] Jeg rømte noget pludseligt af Landet, men jeg svarer Dem omgaaende. Gaa ud og hils paa min Familie! Mange venlige Hilsner Deres altid hengive Carl Nielsen." ${ }^{20}$

Brevet siger i sin korthed en del om dette lærer-elev forhold.

Udover i disse satslære-opgaver er som nævnt også mange af de færdige sange forsynet med rettelser og kommentarer af Carl Nielsen. Som eksempler skal her anføres bemærkninger til tre forskellige kompositioner af Scavenius, det første til en koral og de to sidste til to sange (henholdsvis Vikings Viser og "Hvor frydes alt mit Sind med Sorg"):

"Melodien meget god. Textdeklamationen er ikke helt god. De burde have begyndt paa fuld Takt. Lyder ikke godt med b i Bassen. Det var bedre om Alten fulgte Bassen. Hvad staar der. Hellere b i Bassen."

"Melodien meget god. I første Takt er Bassens 1/8 Delsrytme for tung. Harmoniseringen er helt igjennem lidt tynd, men rigtig følt og skitseret undtagen i $10^{\text {de }}$ Takt hvor Gjentagelsen af samme Harmoni virker kjedeligt, paa $3^{\text {die }}$ i disse kunde en $6^{\text {te }}$ Trins Firklang virke meget godt; tænk selv over det."

"Harmonisering ikke god. Maa vi tale om naar vi ses. Send snart igjen mere!!”

Kun en meget lille del af Scavenius' omfattende produktion blev trykt, og af de talrige værker i manuskript blev formentlig kun et fătal nogensinde kendt uden for Scavenius' arbejdsværelse; langt det meste endte formentlig i skrivebordsskuffen - og senere $i$ en af de store papkasser i den fugtige kælder på Klintholm. Dette ændrer dog ikke ved, at hans allerførste udgivelse, Tre Sange (til tekster af Jeppe Aakjær, Kai Hoffmann og Pierre Ronsard), - tilsyneladende på Carl Nielsens foranledning ${ }^{21}$ udkom på Wilhelm Hansens musikforlag i 1911 i et hæfte forsynet med et omslag, der på for- og bagsiden er dekoreret med et ejendommeligt stik af Ove Scavenius' broder, Maleren Fergus Roger Scavenius, hvis initialer "Fg-R Sca" kan ses i nederste venstre hjørne af omslagets forside. Man må formode at denne forside er inspireret af Ronsards digt, mens bagsiden formentligt illustrer ikke mindst de to sidste vers i Aakjærs "Naar Rugen skal ind."

Nedenstående brev i Rigsarkivet fra Carl Nielsen til Scavenius peger på, at Carl Nielsen har læst korrektur på førstetrykket på vegne af komponisten, 
samtidig med at det i formanende vendinger understreger, at Scavenius nu ikke må hvile på laurabærerne, men fremdeles udvikle sig som komponist:

"Men hør nu! Jeg har faaet Korrektur paa Deres Sange. Vil De have dem sendt eller skal jeg læse Korreturen? Det skal jeg med Glæde Gjøre, men jeg vil have Deres sanktion af Hensyn til Nodestikkeren, Forlæggeren o.s.v. Jeg haaber De arbejder meget flittigt. De maa paa ingen Maade tabe Deres Kompositionsteknik og desuden er det Deres forbandede Pligt at holde Deres Talent vaagent. Vel er det tre kjønne Sange, der nu kommer, men at lægge sig til Hvile paa, er det altfor lidt. Jeg siger Dem forud, kjære Scavenius, at jeg vil have en hel Del Sager at se, naar De kommer til Byen ellers taber jeg Lysten til at arbejde med Dem. [...]."22

De tre sange blev genstand for en lang og stort set positiv anmeldelse i Politiken 2. januar 1911 af avisens mangeårige musikanmelder Hugo Seligmann. ${ }^{23}$ Denne anmeldelse er interessant af mindst to grunde: for det første er det en usædvanlig indgående omtale af en ung, ukendt komponists debutværk i form af tre små sange, og for det andet affødte anmeldelsen en overraskende skarp debat mellem anmelderen og Carl Nielsen, hvoraf dog kun indlægget fra den ene part er bevaret.

Seligmanns anmeldelse bringes nedenfor i sin helhed:

\section{"Ny Musik}

Det er sjældent, man staar overfor ny Musik, der tager En saadan om Hjertet som Ove Scavenius' Sange. Disse 3 smaa Debutsange er i deres enkle Tone og med deres sære, stille Glød saa dejlige, at de brænder sig ind. Det er ikke, fordi de praler med nogen som helst ny 'Mode.' Deres Iklædning er saa kendt og jævn som vel mulig, det er den ganske simple strofiske Form, der straks røber, af hvem Scavenius øser, og hvem han efterligner Carl Nielsen nemlig. Men det gør absolut intet Skaar i disse Sanges Værdi, at de formelt set næsten føles som Pasticher, den mærkelig dybe Følelse, hvoraf de er prægede, bringer En hurtig til at glemme det laante. Det er en nøgen Sjæl, som taler ud af dem. Dernæst taler den, som om Slægtleds Kultur har krystalliseret sig i den fineste Kunst.

I den først af Sangene, til et Digt af Jeppe Aakjær 'Naar Rugen skal ind,' falder maaske netop paa Grund af denne Generations-Fortætning Digt og Musik ikke ganske sammen. Aakjærs er jo selve Muldet, og her er det vel mere Herremandens Søn, for hvis Barneøjne dette Høstbillede ruller sig op, men Digtet forældes unægtelig ved denne Genspejling. ${ }^{24}$ Som Melodi er det den smukkeste Melodi, der endnu er skreven herhjemme til et Aakjærsk Digt, ligesom den følgende Sang, hvis Tekst skyldes Kai Hoffmann, er den eneste af Melodierne til denne Digter, hvori man helt genfinder Hoffmanns vemodige, visionære Lyrik. Heftets sidste Sang er skrevet til en Oversættelse af et Digt af den gamle franske Digter Pierre Ronsard. Stilen er den gammelklassiske, nærmest Glucksk. Dens kysk-ungdommelige, brændende Sværmeri og dens melodiske Sødme gør denne Sang til en af de skønneste Melodier, der i lange Tider er skrevet herhjemme.

Ove Scavenius' 3 smaa Sange er som et Ludvig Holsteinsk Foraar. Selv om han herefter blev tavs for stedse, har han med denne uventede Skønhedsaabenbaring 
gjort en indsats i dansk Musik, som ikke bør overses.

H.S."

Som sagt affødte anmeldelsen en ganske skarp brevveksling mellem anmelderen Hugo Seligmann og Carl Nielsen. Sidstnævnte må have følte sig krænket af anmeldelsens lidt nedladende tone om Ove Scavenius' musik - eller måske af beskyldningen om sangenes efterligning af hans egen stil. Han må have skrevet et brev til Seligmann, som vi ikke kender. Seligmann svarede derefter tilbage i et meget langt brev, som giver en antydning af, hvad Carl Nielsen kan have beklaget sig over i anmeldelsen, og hvordan han ovenikøbet må have sat spørgsmålstegn ved Seligmanns generelle evner som anmelder. Kærnen i Carl Nielsens nu ikke længere kendte kritik af Seligmanns anmeldelse fremgår af nedenstånde afsnit fra Seligmanns brev:

"Hvad Berettigelsen af min Anmeldelse angaar, synes jeg, at naar man tænker paa, hvad der kommer frem af Musik nu om Stunder, staar Scavenius' Sange trods al ydre Paavirkning og Pastiche virkelig højt, saa ungdommelig sarte og ægte som de er, og jeg kan med min bedste Vilje ikke forstaa, som De mener, at det kan være at gøre stor Skade at henlede Opmærksomheden paa dem, saaledes som jeg har gjort: sige, at her er noget ualmindelig smukt, som ikke bør overses, noget som har Værdi i sig selv. At ogsaa De synes, at de har det, ser jeg jo tydeligt af Deres Brev. Jeg tror derfor ikke, De har Ret i at kalde min Begejstring hysterisk, det er mig naturligvis umuligt selv ganske at bedømme Virkningen af mine Ord, men jeg kan slet ikke forstaa, at $D e$ kan finde mit 'Favntag groft' og se 'Næver' hvor jeg netop synes, at jeg har taget saa nænsomt." 25

Umiddelbart passer det dårligt ind i det indtryk, man fra andre sammenhænge får af Carl Nielsens meget beskyttende forhold til Ove Scavenius, såfremt han - som Seligmanns brev tyder på - har beklaget sig over en alt for positiv omtale af de tre sange. Hvis det er dette, der er sagens kærne - altså at Carl Nielsen fandt Seligmanns anmeldelse helt overdreven positiv - må man give ham ret. At kalde melodien til Aakjærs "Nu er det længe siden" for "den smukkeste Melodi" der er er skrevet til en tekst af Aakjær og den afsluttende melodi til Ronsards "Følg mig -" for "en af de skønneste Melodier, der i lange Tider er skrevet herhjemme," må siges at tage munden fuld. Man må formode, at disse vurderinger har stødt Carl Nielsen, som på dette tidspunkt dog selv havde komponeret en række danske sange, dels mere kunstprægede til tekster af I.P. Jacobsen og Ludvig Holstein, dels rent folkelig fællessange i hæftet Strofiske Sange opus 21 (CNW Coll. 5).

Hele denne sag kompliceres yderligere af det forhold, at det fremgår af Scavenius' originalmanuskript af "Naar Rugen skal ind," at Carl Nielsen har været inddraget i tilblivelsen af sangen; dels viser manuskriptet, at det er Carl Nielsen, der har foreslået, hvilke af Aakjærs oprindelige 11 vers der bør udelades (Aakjærs vers 4-7 og v. 11), dels at han har foreslået et par afgørende ændringer, som alle er kommet med i den trykte udgave (t. 2-4, t. 8, t.10 samt t. 10-14).

En lille detalje i dette lærer-elev forhold fremgår af slutningen af et af Carl Nielsens breve: "I Deres Brev fra i Sommer spørger De om mit Honorar 
for sidste Vinter. Vi kan jo sige $100 \mathrm{Kr.}{ }^{26}$ Ifølge Danmarks Statistiks Prisberegner svarer dette til $6.517 \mathrm{kr}$. i 2016. Det ville man næppe få en løbende undervisning for i dag hos en af landets førende komponister.

\section{Nodesamlingen fra Klintholm}

Samlingen af Ove Scavenius' musikhåndskrifter er, som det er nævnt ovenfor, ganske omfattende. Skønsmæssigt omfatter den knap en hyldemeter, hvoraf ca. halvdelen består af færdige eller næsten færdige kompositioner, mens den anden halvdel består af uordnede skitser og fragmenter, som muligvis efter en nøjere undersøgelse vil kunne identificeres. Skriveredskaber og skrift i det hele taget varierer i påfaldende grad, rækkende fra en sirlig blækrenskrift til en næsten ulæselig, hastigt nedkradset nodesats, som undertiden ligefrem udvikler sig til kruseduller, der slet ikke synes at have med nodesats at gøre. En række af de færdige kompositioner - men langt fra alle - er slutdateret af komponisten; i sådanne tilfælde hyppigt dateret til perioden 1903-1910, idet der dog også findes enkle dateringer fra hans modne år. Værkerne med Carl Nielsens rettelser eller kommentarer synes næsten uden undtagelse at stamme netop fra årene før og efter 1910. Ud over disse håndskrevne nodeblade indeholdt den oprindelige samling en række trykte noder af Carl Nielsen, ofte med personlig dedikation til Ove Scavenius; disse nodetryk blev ved overdragelsen af samlingen til Det Kgl. Bibliotek udtaget af Ove Scavenius' samling.

Langt den overvejende del af produktionen omfatter sange; derfor er de meget få værker, han fik udgivet, også sange. Det gælder dels hans "debutværk", 3 Sange af: Jeppe Aakjar, Kai Hoffmann og Pierre Ronsard, omtalt mere indgående i det foregående, dels yderligere seks enkelttryk af sange i meget beskedent udstyr: Media vita og Sommeraften af Johannes Jørgensen, Hochzeitlied af Jacobi, I Haugen af Aarestrup, Sne ${ }^{27}$ af Helge Rode samt den tidligere nævnte Salme ("Tag min Sjæl, naaderige Gud" fra romanen Jens Langkniv) af Aakjær. Hertil kommer et par sange i Carl Nielsens udgave af nye melodier til Johan Borups Sangbog fra 1916 (Sne og Deroppe er Himlen saa blaa). Som det gjaldt for hans lærer Carl Nielsen, lader det også til at have været vigtigt for Ove Scavenius at vælge sine tekster blandt de førende danske digtere, hvoraf som de vigtigste skal nævnes: Jens Baggesen, Ludvig Holstein, J.P. Jacobsen, Johs. V. Jensen, Thøger Larsen, Adam Oehlenschläger, Helge Rode, Emil Aarestrup, og Jeppe Aakjær.

To af sangene skal omtales nærmere her: Skumring til tekst af Viggo Stuckenberg og de forskellige udsættelser af Ove Rodes Sne. Førstnævnte sang må være blevet til, mens Scavenius var elev hos Carl Nielsen. Som det fremgår af nedenstående illustration har satsen oprindeligt foreligget i Scavenius' blækrenskrift med en lidt tung harmonisering. Herefter har Carl Nielsen med blyant forenklet satsen, foreslået den transponeret til As dur og på sædvanlig opmuntrende vis - noteret "Send snart igjen mere!!" efter dog først at have tilkendegivet sin mening om harmoniseringen: "Harmonisering ikke god! Maa vi tale om naar vi ses."

Helge Rodes digt, Sne, som senere blev kendt med både Thomas Laubs og Povl Hamburgers melodier (henholdsvis 1926 og 1937), har også optaget Ove Scavenius i betydelig grad; den findes i 
Scavenius' manuskript til sangen Stemning med Carl Nielsens blyantsrettelser; nedenfor transskription af satsen, som Carl Nielsen har foreslaet den.

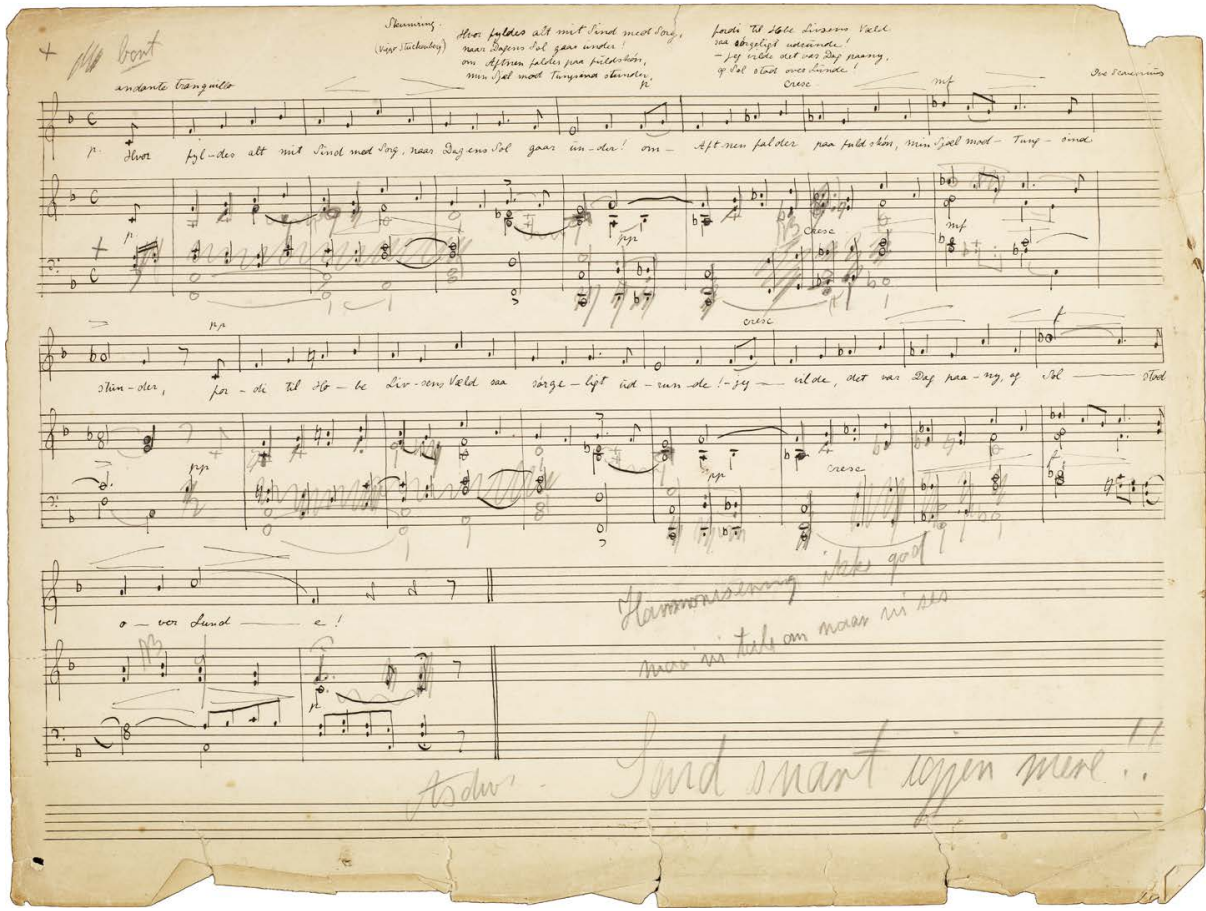

\section{Stemning}

Ove Scavenius

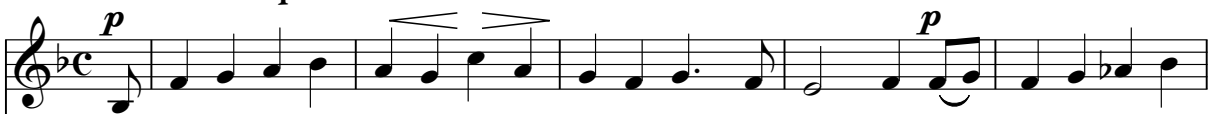

andante tranquillo

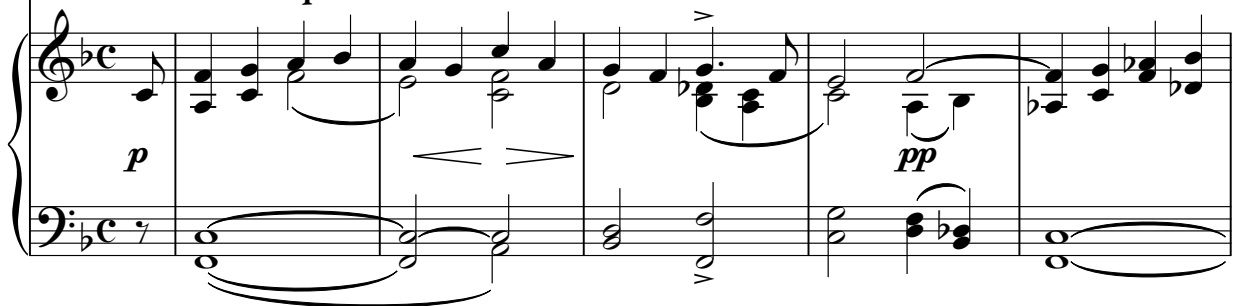



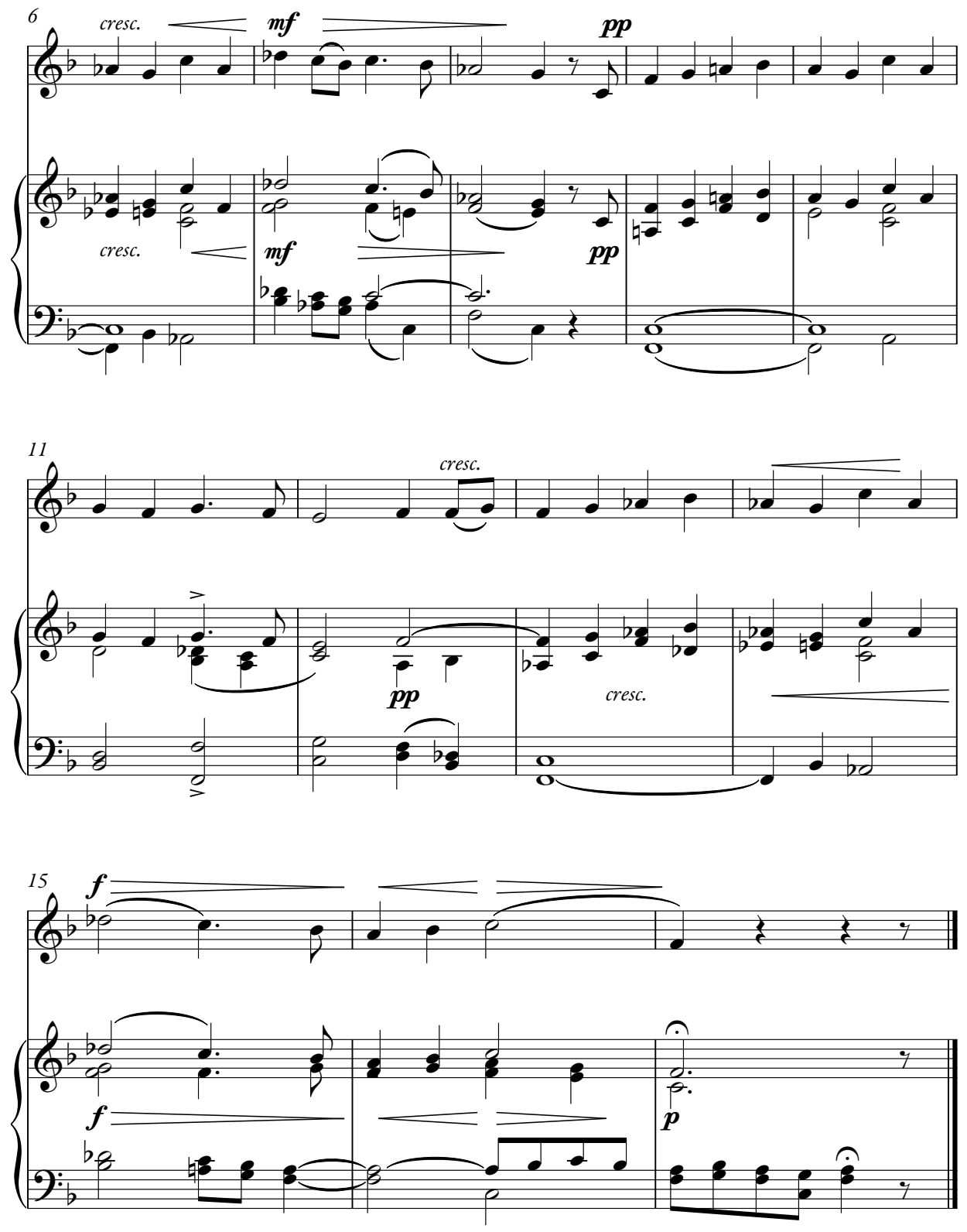


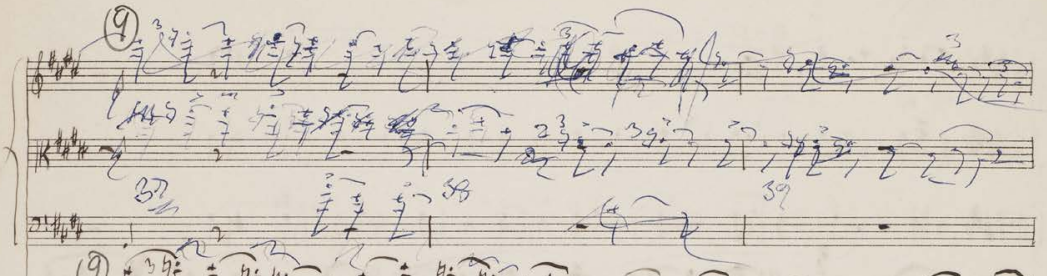

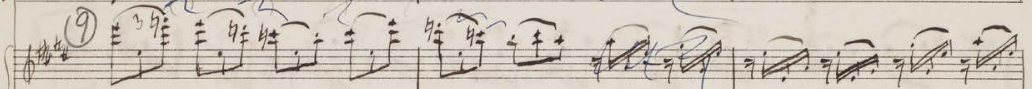
o:d,

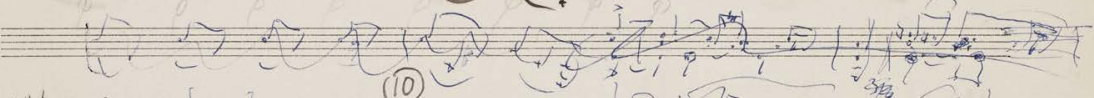

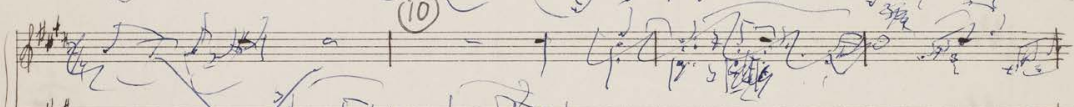

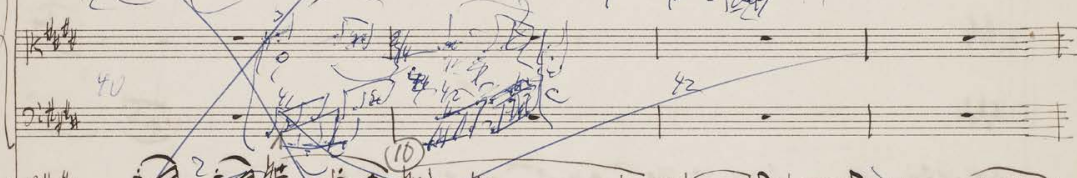
(2) 40.190.

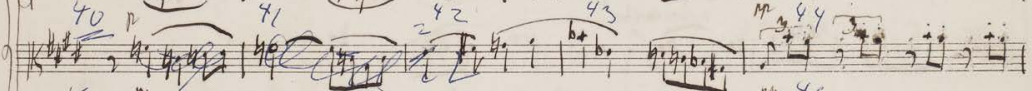

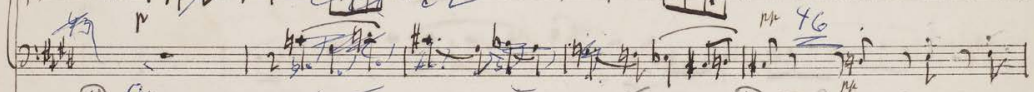

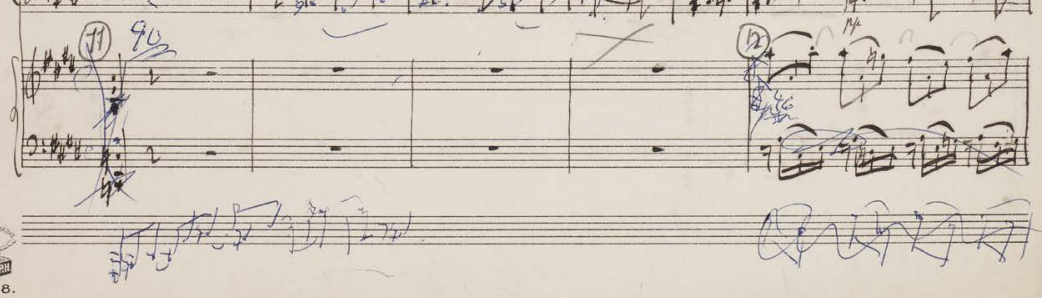

Klaverkvartet, 2. sats. Det er vanskeligt at afgore, om de mange rettelser er foretaget for eller efter udskriften af de professionelle stemmer. 
ikke færre end fire forskellige udsættelser, to for sang og klaver og to for blandet kor - den ene af korudsættelserne udformet som en tostemmig homofon udsættelse af melodien i tenor og bas med et flydende ottendedels kontrapunkt i overstemmerne på stavelsen "A ..." Fra et par breve fra dirigenten for Bel Canto, Vilhelm Poulsen, vides det, at han og hans kor havde korsatserne på programmet, og at han oven $\mathrm{i}$ købet opfordrede Scavenius til at forsyne Bel Canto koret med yderligere satser. ${ }^{28}$ Han var angiveligt blevet opmærksom på Scavenius' melodi gennem Nye Melodier til de Nyere Sangtekster i Johan Borups Dansk Sangbog, redigeret af Carl Nielsen og udkommet i 1916. Her optræder netop Ove Scavenius' melodi til Sne sammen med en række andre enstemmige melodier af Carl Nielsen selv og en række af hans andre elever. ${ }^{29}$ Knap 10 år senere vendte Carl Nielsen tilbage til Scavenius' melodi i forbindelse med sit arbejde omkring Sangbogen "Danmark"; her arrangerede han melodien for to lige stemmer (se musikeksemplet til slut).

Ud over de mange - fortrinsvis strofiske - sange indeholder materialet en række mere prætentiøse kompositioner, dels værker med vokalt islæt, dels rent instrumentale værker. Et lille udvalg af disse større værker skal kort nævnes her til slut, idet det gælder for mange af dem - om muligt i endnu højere grad end for sangene - at overleveringen er meget forvirrende med rettelser, manglende sider, ulæselig skrift etc.:

- Timerne for kor og stort orkester. Kompositionen består af fire satser, Dag - Morgen - Middag - Aften, overleveret dels som et 50 sider langt partitur, dels i et læg med mere end
100 siders skitser. Tekstforfatteren er ukendt

- Lille Suite for Strygeinstrumenter (3 satser: Quasi Minuetto, allegretto Adagio e molto cantabile - Rondo), formentlig inspireret af Carl Nielsens Suite for Strygeorkester (CNW 32), overleveret i partitur i Ove Scavenius hånd og udskrevne stemmer i professionel hånd. Materialet bærer præg af, at værket har været opført, bl.a. fordi der foreligger adskillige kopier af hver af de fire stemmer, vl. 1 og 2 ( 7 af hver stemme), va. (4 kopier), vc. (3 kopier) og bas (2 kopier).

- Sonatefor violin og klaver, meget virtuost anlagt værk, hvor kun første og tredje sats tilsyneladende er bevaret i nodesamlingen i Det Kgl. Bibliotek. Ifølge brev fra Irmelin blev sonaten opført i 1962 af violinisten Niels Nielsen og pianisten "Fru Fellsing." ${ }^{30}$

- Klaverkvartet (vl., va., vc., klaver). 49 siders partitur i Scavenius' hånd samt professionel renskrift af de tre strygere. Udstreget datering "Klintholm 1930" (delvis ulæseligt). Efterhånden som partituret skrider frem, bliver skriften mere og mere ulæselig, således som det fremgår af partitursiden fra 2. sats gengivet ovenfor.

\section{Afslutning}

Ovenstående beskrivelse af en glemt dansk komponist er udelukkende tænkt som en præsentation af det overleverede kildemateriale i form af noder og breve samt en beskrivelse af hans forhold til sin lærer, Carl Nielsen, på baggrund af et materiale - nodesamlingen i Det Kgl. Bibliotek og den store samling breve til Scavenius i Rigsarkivet - som ikke tidligere synes at have påkaldt sig nogen 
interesse. En eventuel karakteristik af Ove Scavenius som komponist vil kræve en grundig analyse af det omfattende nodemateriale; ligeledes kunne en mere systematisk undersøgelse af materialet tegne et klarere billede af Carl Nielsens metoder som lærer i komposition. Begge dele har ligget uden for rammerne af nærværende artikel.

Som afsluttende vidnesbyrd om Carl Nielsens interesse og omsorg for Ove Scavenius skal citeres et udateret brev til Scavenius, skrevet efter at Carl Nielsen var flyttet ind i sin hustrus "xresbolig" $\mathrm{i}$ Frederiksholms Kanal, det vil sige efter 1915. Her mærker man tydeligt Carl Nielsens velkendte empati, skrevet på et tidspunkt, hvor man må formode, at det egentlige lærer-elev forhold er ophørt:

\section{"Frederiksholms Kanal 28A}

Kære Ove Scavenius! Hvordan mon De har det? Jeg kan ikke nægte, at jeg tænker ofte paa Dem og længes af og til efter at se Dem og høre og se hvad De laver. Kommer De ikke til Byen i Vinter? - Mon De skulde gaa i den Tro, at jeg ingen Interesse har for Dem og Deres Udvikling? Det er min Samvittighed, der taler. Ikke fordi den just er saa slet, men at den overhovedet lader sig mærke er jo ogsaa slemt nok. For mig selv maa jeg indrømme at der er ingen Mening i forholdet mellem det Venskab jeg nærer for Dem og det Udslag eller Mangel paa Udslag det faar. Det er egentlig ret trist som det gaar og jeg vil betro Dem, at ofte, naar der er saa mange Ting der stiller Krav til mig, kan jeg blive ganske modfalden fordi ikke alt overkommes som det burde og jeg har i saadanne Øjeblikke mest Lyst til at smide alt fra mig og løbe min Vej ned til Dem og bede om jeg maa gemme mig nogle Dage i Deres Hytte. Den spiller en vis Rolle i min Fantasi. Skal det aldrig blive til andet? Jeg haaber bestandig; maaske til det bliver for sent. Hvad ved vi?- Deres Moder vilde smile hvis hun hørte mig i denne Jeriminade; flere Gange, har hun bedt mig komme og besøge Klintholm og aldrig kan det blive. Men, kære Ove Scavenius! Lad mig høre hvad De arbejder med. Har De fortsat med Instrumentation? Eller har De forenet begge Dele og komponeret for Orkester? - De kan jo saa meget, at De godt kan arbejde selv; men skulde De have Lyst og Trang til at udveksle Tanker med mig ved et Gennemsyn, saa ved De jo saa sikkert, at jeg modtager Dem altid med aabne Arme.- Her gaar det som sædvanligt med Arbejde til alle Sider. Min Kone spørger, trods din Travlhed ogsaa efter Dem og vi alle sammen taler om hvornaar De mon kommer herind. - Skriv til mig og fortæl rigtig hvordan det gaar og naar vi ses. Vil De hilse Deres Moder meget fra mig og selv modtage de bedste Hilsener fra Deres hengivne Carl Nielsen" ${ }^{\text {31 }}$ 


\section{Sne}

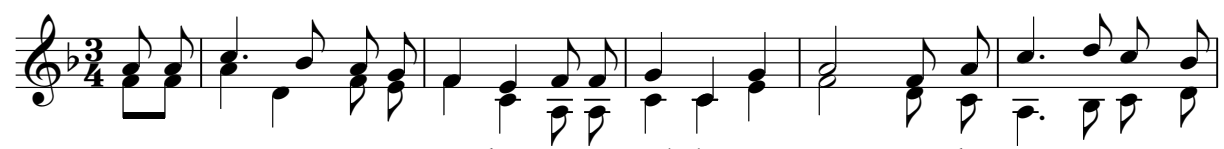

Der er in - genting i Verden saa_ stil-le som Sne, naarden sag - tegennem
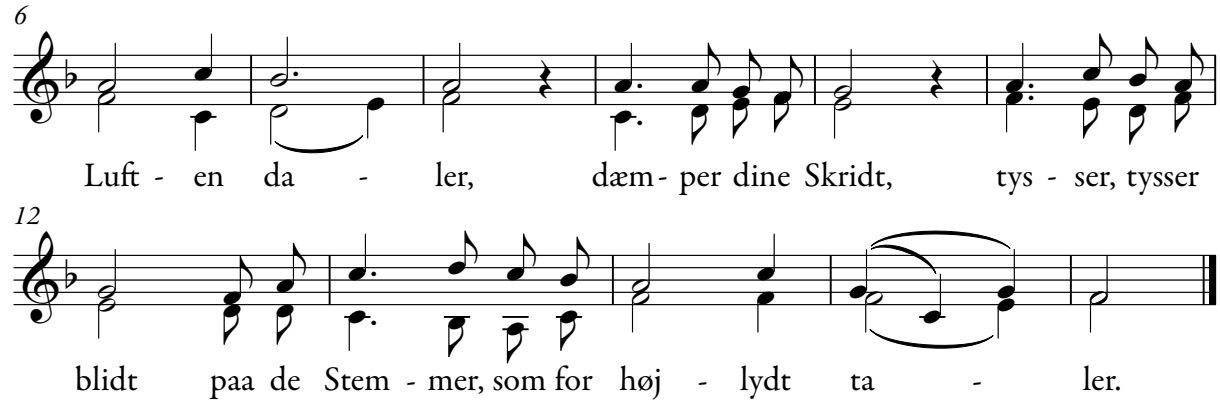

Melodi af Ove Scavenius, understemme af Carl Nielsen. Fra Melodier til Sangbogen Danmark, 1924 (CNW B44)

\section{Noter}

1 Statens Arkiver, 08101. Scavenius, Ove. Breve fra andre, alfabetisk henlagt. Ingen af de pågxldende breve er gengivet i Carl Nielsen, Brevudgaven.

2 Gustav Hetsch, Det kongelige danske Musikkonservatorium 1867-1917, Med en Fortegnelse over samtlige Elever, København 1917; i elevfortegnelsen her er Ove Scavenius' navn ikke anført.

3 Brevet i Rigsarkivet indgår i Ove Scavenius' samling, hvilket kan undre, eftersom det er tale om en anbefalingsskrivelse til tredjemand.

4 Ud over de i denne artikel nævnte private breve fra Ove Scavenius' slægtninge giver nekrologen i Nestved Tidende 2. august 1973 den mest indgående beskrivelse af hans liv og karriere. Her hedder det bl.a., at Scavenius først blev elev af Carl Nielsen i 1910, hvilket dog ikke stemmer overens med det faktum, at der findes rettelser af Carl Nielsen i manuskripter, dateret af Scavenius tilbage i 1903.

5 Brev fra Carl Nielsen til Ove Scavenius, Rigsarkivet 3.9.1907.

6 Brev fra Carl Nielsen til Ove Scavenius, Rigsarkivet 2.11.1907.

7 I indledningen til Brevudgaven bd. 11, s. 23 anføres det, at Ove Scavenius havde været kæreste med Irmelins yngre søster Anne Marie (kaldet Søs); det er næppe korrekt.

8 Brev fra Irmelin til Anne Marie, 1.9.1912, CNB 4/427. 
9 Brev fra Irmelin til Anne Marie, 26.5.1915, CNB 5/217.

10 Brev fra Irmelin til Anne Marie, 20.9.1915, CNB 5/275.

11 Brev fra Irmelin til Anne Marie 27.8.1918, CNB 6/111.

12 Brev af 21.3.1912, Rigsarkivet, Ove Scavenius' Samling.

13 6.7.1912, Rigsarkivet, Ove Scavenius' Samling.

14 Brev af 22.9.1912, Rigsarkivet, Ove Scavenius' Samling.

15 Brev af 24.6.1919, Rigsarkivet, Ove Scavenius' Samling

16 Brev fra Carl Nielsen til Aakjær, 9.4.1917, CNB 5/492.

17 Satsen findes i KB's musiksamling under opstillingssignaturen D290, 1917 1918.195.

18 Brev i Rigsarkivet fra Carl Nielsen til Ove Scavenius 19.4.17: "Jeg har faaet Brev fra Aakjær. Han beder saa mindelig om "Satan" maa blive staaende. Deri maa vi vel saa følge ham, og det kan jo ogsaa nuanceres som Deres Broder, De og jeg talte [om] og derved faar en særlig Karakter."

19 Knud Jeppesen, Palestrinastil med serligt Henblik paa Dissonansbehandlingen, København 1923.

20 Postkort af 6. juni 1911 (ikke i Brevudgaven), samme dag som Carl Nielsen netop var ankommet til Troldhaugen.

21 Se dagbogsnotat 16.6.1910: "Hos Wilh: Hansen med O. Scavenius som faar sine tre Sange ud" (CNB 3/846).

22 Brev af 21.10.1910, Rigsarkivet, Ove Scavenius' Samling.

23 Hugo Seligmann var ligesom Scavenius elev af Carl Nielsen og i øvrigt en stor beundrer af sin lærer. I 1931 udgav han en monografi om Carl Nielsen, den første af sin art efter Carl Nielsens død.
24 Anmelderen tænker vel her på, at digtet bygger på den fattige jydske bondedrengs erindringer, mens melodien er skrevet af godsejerens søn på Klintholm. Trods anmeldelsens positive ord slog Scavenius' melodi aldrig an; i 1940 komponerede Oluf Ring den i dag velkendte melodi til samme tekst, som fra og med Folkehøjskolens Melodibogs fjerde udgave fra 1940 har været den gængse. Et opslag på internettet af sangens titel kombineret med Scavenius' navn resulterer ikke i et eneste hit! Trods den positive modtagelse blev Scavenius' melodi således totalt glemt af eftertiden.

25 Brev fra Hugo Seligmann til Carl Nielsen, 11/1 1911, CNB 4/4. Som nævnt kendes Carl Nielsens forudgående brev til Seligmann ikke.

26 Brev i Rigsarkivet af 1.11.1907.

27 Samme melodi overleveret i ikke færre end fire forskellige varianter.

28 Breve fra Vilhelm Poulsen til Ove Scavenius i perioden 6.10.1920 til 24.1.1923, Rigsarkivet, Oves Scavenius' Samling.

29 Thorvald Aagaard, Paul Hellmuth, Nancy Dalberg, A. Riis-Magnussen m.fl. Alette Scavenius har oplyst, at på trods af at Scavenius' melodi til Ove Rodes tekst Sne på det pågældende tidspunkt var glemt og erstattet af Povl Hamburgers melodi, gjorde man i hendes tidlige skoleår på Møn i slutningen af halvtredserne meget ud af, at det skam var den lokale komponist Ove Scavenius' melodi man dér sang i skolen.

30 Brev fra Irmelin til Ove Scavenius, Rigsarkivet, Ove Scavenius' Samling. Ifølge brevet var Irmelin behjælpelig med at få nodematerialet kopieret med henblik på opførelsen. Dette nodemateriale synes ikke at være bevaret.

31 Udateret brev, Rigsarkivet, Ove Scavenius' Samling. 